\title{
The Positive Effect of Micro-Dams for Groundwater Enhancement: a Case Study around Tsinkanet and Rubafeleg Area, Tigray, Northern Ethiopia)
}

\author{
${ }^{*}$ Dessie Nedaw ${ }^{1}$ and Kristine Walraevens ${ }^{2}$ \\ ${ }^{1}$ Mekelle University, Ethiopia, College of Natural and Computational Sciences, Department of \\ Applied Geology, P.O.Box 231, Mekelle (*dessienedaw@yahoo.com) \\ ${ }^{2}$ Ghent University, Belgium, Laboratory for Applied Geology, Department of Geology and Soil \\ Science, Krijgslaan 281 - 58 - B - 9000 Gent.
}

\begin{abstract}
The government of Tigray Regional State, Northern Ethiopia has been conducting a massive construction of micro-dams (small reservoirs) in order to decrease the rainfall dependency and alleviate food insecurity in drought prone areas of the region. Tsenkanet and Rubafeleg reservoirs are examples of this endeavor. The purpose of this investigation is to evaluate the role of these micro-dams in enhancing the surrounding groundwater by artificial recharge. In this study the physical characteristics of the reservoir are discussed including the groundwater surface water relationship with respect to water level elevation and also hydro-chemical composition. Six water samples have been analyzed. Samples are taken after rinsing the plastic bottles with distilled water and the sample to be taken. One surface water sample from each reservoir and one groundwater samples from each well next to each reservoir has been collected. Moreover, one sample from spring and one from river has been analyzed. The chemical composition of the reservoir water and the surrounding groundwater seem to suggest a similar origin and to be resulting from similar hydro-chemical processes. The chemical composition of all samples is found to be of the $\mathrm{CaHCO}_{3}$ type, which could be explained as resulting from precipitation water in which the mineral calcite has been dissolved. Both the topographic evidence and the water level monitoring data has confirmed the feeding of the reservoir to the near by shallow groundwater system. Quantifying the amount of groundwater accretion by the use of modeling and water balance method is recommended.
\end{abstract}

Keywords: Groundwater, Surface water, Topography, Water Level, Type, Hardness, Class.

\section{INTRODUCTION}

Water scarcity and unwise management is a global concern especially in sub-Saharan countries. Global fresh water demand is alarmingly increasing with increase in population and civilization. As industrial, agricultural and domestic pollution threaten existing supplies - water becomes increasingly precious resource.

Ethiopia surface water and groundwater resources have been regarded as high giving a name to the country as the water tower of east Africa (Said, 1993). This is factually true when considering half of the country, particularly the western and south western part of the country. 
The endowment can be used for productive purpose that can transform the countries socio economy (Selashi, 2007). Unfortunately its uneven distribution in space and time coupled with poor management and development of the resource lead the country to a repeated famine resulting from drought (FAO, 2005).

The Tigray Regional State is in the northern part of the country, where drought and subsequent famine was common in the past. Geba catchment, the Project area is characterized by intermittent rivers which are dry 8 to 9 months with arid and semi arid climatic condition. The main socio-economic activity in the area is rain fed agriculture which directly linked to the erratic rainfall. To alleviate this rainfall dependency which is full of uncertainty the regional government has devised a mechanism by which it can supplement the rain fed agriculture with irrigation by constructing micro-dams. This task was mainly assigned for a governmental organization named Co-SEART (Commission for sustainable agriculture and environmental rehabilitation of Tigray). The activity of the organization has been stopped after constructing 60 micro-dams because it has been believed that they are less effective in supporting the rain fed agriculture through small scale irrigation schemes for institutional, technical and socio economic reasons. Therefore the purpose of this investigation was to evaluate the role of these seemingly failed micro-dams in enhancing the surrounding groundwater system by artificial recharge. The specific objective of this study were to investigate first the interaction of these reservoir with the surrounding groundwater and if possible to quantify the total amount of recharge from the reservoir to the surrounding groundwater system.

\section{METHODOLOGY}

To achieve the above mentioned objective three wells labeled as Tsinkanet Well 1 (TSW1), Tsinkanet Well 2 (TSW2) and Rubafeleg well (RFW) and two micro dams labeled as Rubafeleg Dam (RFL) and Tsinkanet Dam (TSL) have been closely examined. The water level fluctuation (both in the dams and wells) has been monitored for nearly two years with the average interval of 2 hours, in order to see change of the water level in response to rainfall and recharge. As the general purpose is to monitor the interaction between the reservoirs and the groundwater system the impact of irrigation was not considered in this investigation. The water level both in the well and the reservoir is monitored by TD DIVERS, by which a continuous record of temperature and water depth is recorded from November 2004 to December 2006 with an interval of 2 hours. In 
order to be accurate on the elevation difference between measuring points of the diver altimetry leveling has been conducted.

Water samples collected from Tsinkanet and Rubafeleg on Jan 6, 2006 and March 14, 2006 have been analyzed in Belgium and Ethiopia. Four water samples were analyzed in the Laboratory of Applied Geology, Department of Geology and Soil Sciences, University of Ghent, Belgium and two samples were analyzed at department of Earth Science, Mekelle University. For the Ca++, $\mathrm{Mg}++, \mathrm{Na}+, \mathrm{K}+, \mathrm{Fe}, \mathrm{Mn}$, and $\mathrm{Si}$ Varian AAS has been used and for $\mathrm{HCO}_{3}$ titration method is used and NO3, SO4, Cl, and PO4 UV spectrophotometer is used. The accuracy of the analysis has been tested using ionic balance (Appelo and Postma, 1996). In all but one the balance is found to be less than $5 \%$. This indicates that the analysis is sufficiently accurate. In order to interpret and classify the water a new classification scheme developed by Stuyfzand (1986) is adopted. The classification starts with main type based on Chloride concentration, then each main type is subdivided to type based on total hardness, then each type is further subdivided into sub type based on the proportional share of main constituents in the sum of cations and anions in meq/l, finally each sub type is further classified to classes by using the following formula (Na + $\mathrm{K}+\mathrm{Mg})_{\text {corrected }}=(\mathrm{Na}+\mathrm{K}+\mathrm{Mg})$ measured $-1.061 \mathrm{Cl}(\mathrm{meq} / \mathrm{l})$

\section{LOCATION AND ACCESSIBILITY}

Geba-catchment has an area $5133 \mathrm{~km}^{2}$. The elevation ranges from $955 \mathrm{~m}$ a.m.s.l to $3295 \mathrm{~m}$ a.m.s.l. The mean elevation has been found to be $2146 \mathrm{~m}$, a.m.s.l. Entire Geba catchment is found between $39^{\circ} 30^{\prime}$ to $40^{\circ} 00^{\prime} \mathrm{E}$ (longitude.) and $13^{\circ} 45^{\prime}$ to $14^{\circ} 15 \mathrm{~N}$ (latitude) figure 1.

Tsinkanet and Rubafeleg area are found in the upper catchment of Geba along the west and east boundaries respectively (figure 1). In both areas there is a reservoir on upstream side and shallow hand dug wells in the command areas. The UTM location of the reservoirs and the shallow hand dug wells where monitoring is conducted is shown on table 1.As one can see from the table the Monitoring well at Tsinkanet is 400 meter west of the reservoir where as the monitoring well at Rubafeleg is more than $1 \mathrm{~km}$ North of the reservoirs. Both reservoirs are not more than $1 \mathrm{~km}^{2}$ area, and there depth is not more than 10 meter. Tsinkanet Area is found between (561500 555500 UTME and 1552100 - 1546000 UTMN) and Rubafeleg area is found between (581700 575700 UTME and 1543000 - 1537500 UTMN). 
The study area is accessible by all weather roads running from Hawzen to Senkata and from Atsbi to Dera.

Table 1. UTM location of water points used for monitoring.

\begin{tabular}{|l|l|l|l|l|l|l|}
\hline $\begin{array}{l}\text { Name of Water } \\
\text { point }\end{array}$ & $\begin{array}{l}\text { Tsinkanet } \\
\text { well } \\
\text { 1(monitoring } \\
\text { Well) } \\
\text { (TSW1) }\end{array}$ & $\begin{array}{l}\text { Tsinkanet } \\
\text { well 2 } \\
\text { (TSW2) }\end{array}$ & $\begin{array}{l}\text { Tsinkanet } \\
\text { (center of } \\
\text { dam Axis) } \\
\text { (TSL) }\end{array}$ & $\begin{array}{l}\text { Rubafeleg } \\
\text { well } \\
\text { (RFW) }\end{array}$ & $\begin{array}{l}\text { Rubafeleg } \\
\text { (center of } \\
\text { dam Axis) } \\
\text { RFL }\end{array}$ \\
\hline \multirow{2}{*}{ Location } & UTMN & 1549139 & 1549080 & 1541634 & 1540500 \\
& UTME & 558303 & & 558723 & 578715 & 578700 \\
\hline
\end{tabular}

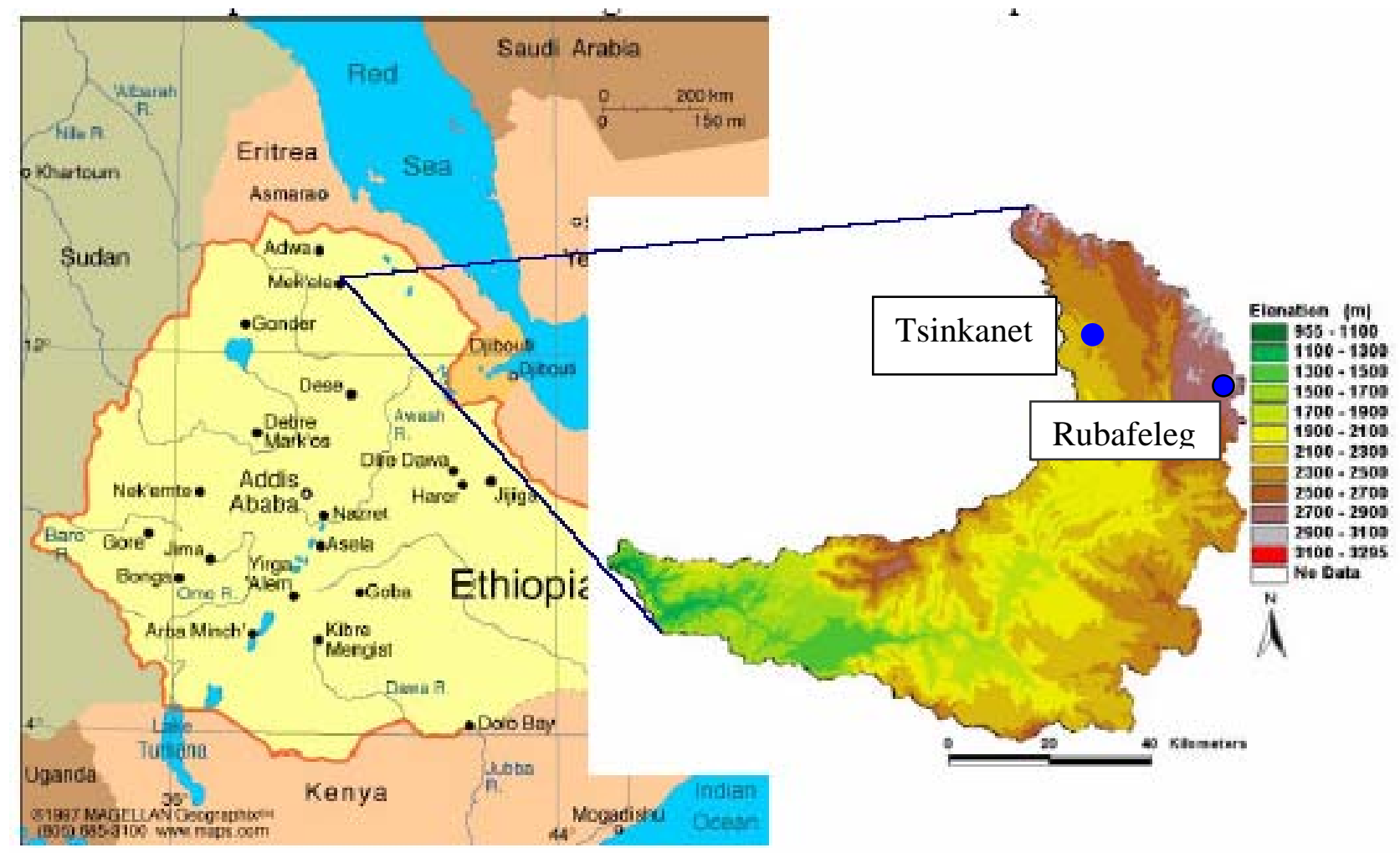

Figure1. Location map of Geba catchment, Tsinkanet and Rubafeleg Area (USGS, 2004). 


\section{GEOLOGY AND HYDROGEOLOGY OF THE STUDY AREA}

The study area is mainly characterized by basement complex of Precambrian age, composed of meta-volcanics and meta-sediments (Kazmin, 1978). These are exposed in most parts of the mapped area.

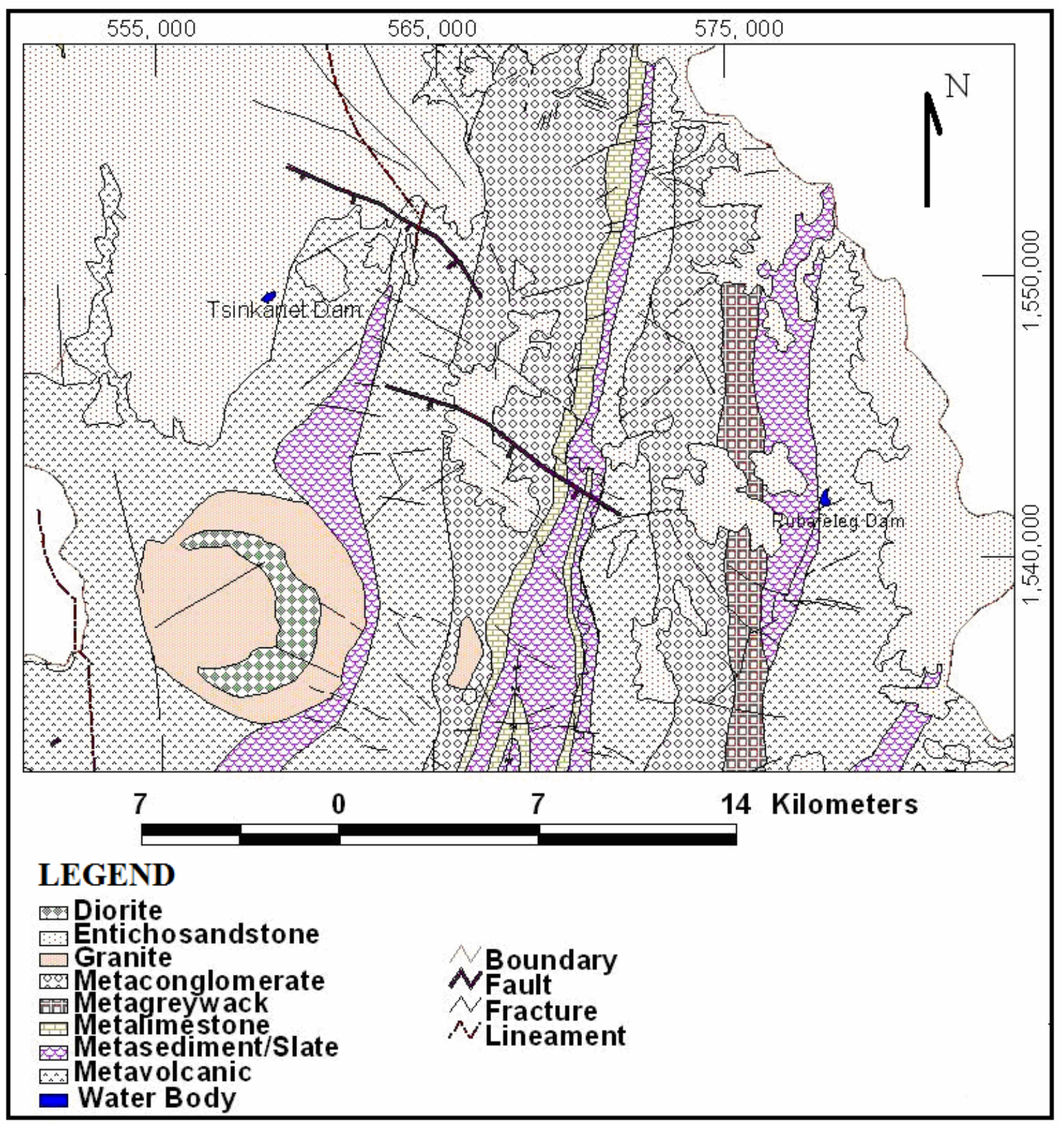

Figure 2. Geological Map of Northern Geba Catchment (Modified after Tesfamicheal Gebreyohannes et al., 2009) 
At the eastern most part and along the northwestern part Paleozoic sandstone is exposed. In the southwestern part a younger granite intrusion is mapped cross cutting the basement complex as shown in figure 3. Since the area is mainly characterized by crystalline metamorphic rocks, the groundwater availability and movement is mainly controlled by fractures and weathering zones. The main water supply for drinking and small scale irrigation is the groundwater tapped from boreholes to a maximum depth of $50 \mathrm{~m}$ and hand dug well with a maximum depth of 10 meter. In Tsinkanet area the reservoir is mainly characterized by Enticho sandstone, with a thickness not more than a couple of meters. At the command area the sandstone thins out and the underlying metavolcanic rock is exposed. In Rubafeleg area both the reservoir and the command area are characterized by metamorphic rocks mainly metavolcanic and Metasediments.

\section{RESULTS AND DISCUSSION}

\subsection{Geomorphologic analysis from Topographic and Shuttle Radar Topographic Mission (SRTM, 2004) data}

Topographic position is one of the governing factors that control the direction of groundwater flow. In the area the geographic location of the reservoir and the aquifer system is in a suitable location enabling the reservoir to feed the groundwater. In addition the high degree of fracturing and weathering also encourage the down gradient flow of the seepage water. Accordingly the subsurface water downstream to the reservoir is under favorable location for groundwater recharge figures 3 and 4.

\subsection{Water level Analysis}

Water level both in the reservoir and the surrounding groundwater was being monitored since late 2004 in Tsinkanet and Rubafeleg area. Monitoring has been conducted for more than two years till December 2006. As it can be seen on the following graphs (Figure 6 \& 7) the following observations are seen.

- $\quad$ The head in the micro-dam is always higher than that of the wells during the recorded period.

- Moreover the general trend of water level change both in the reservoir and in the well with respect to time is more or less similar. 


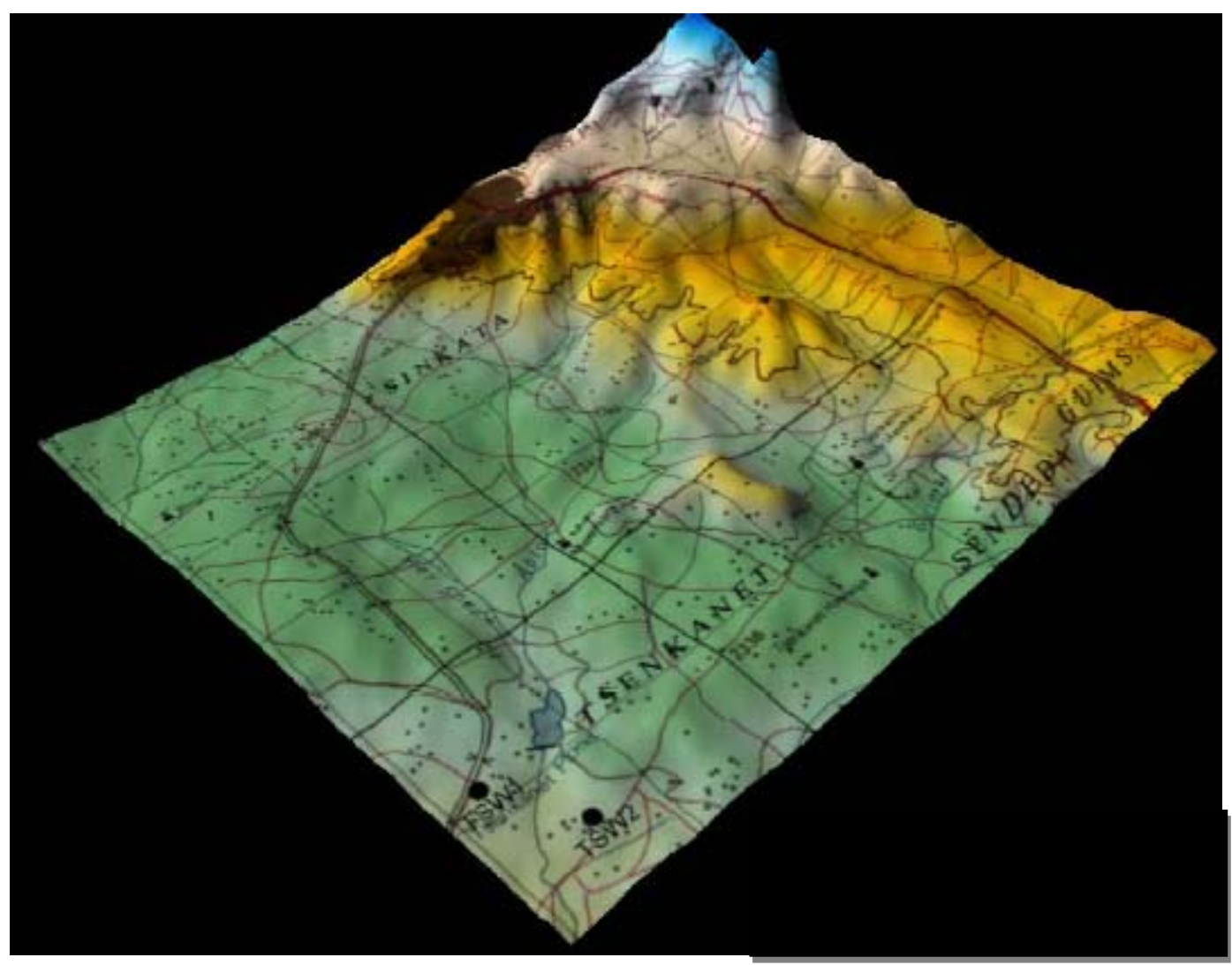

Figure 3. Tsinkanet Area topography.

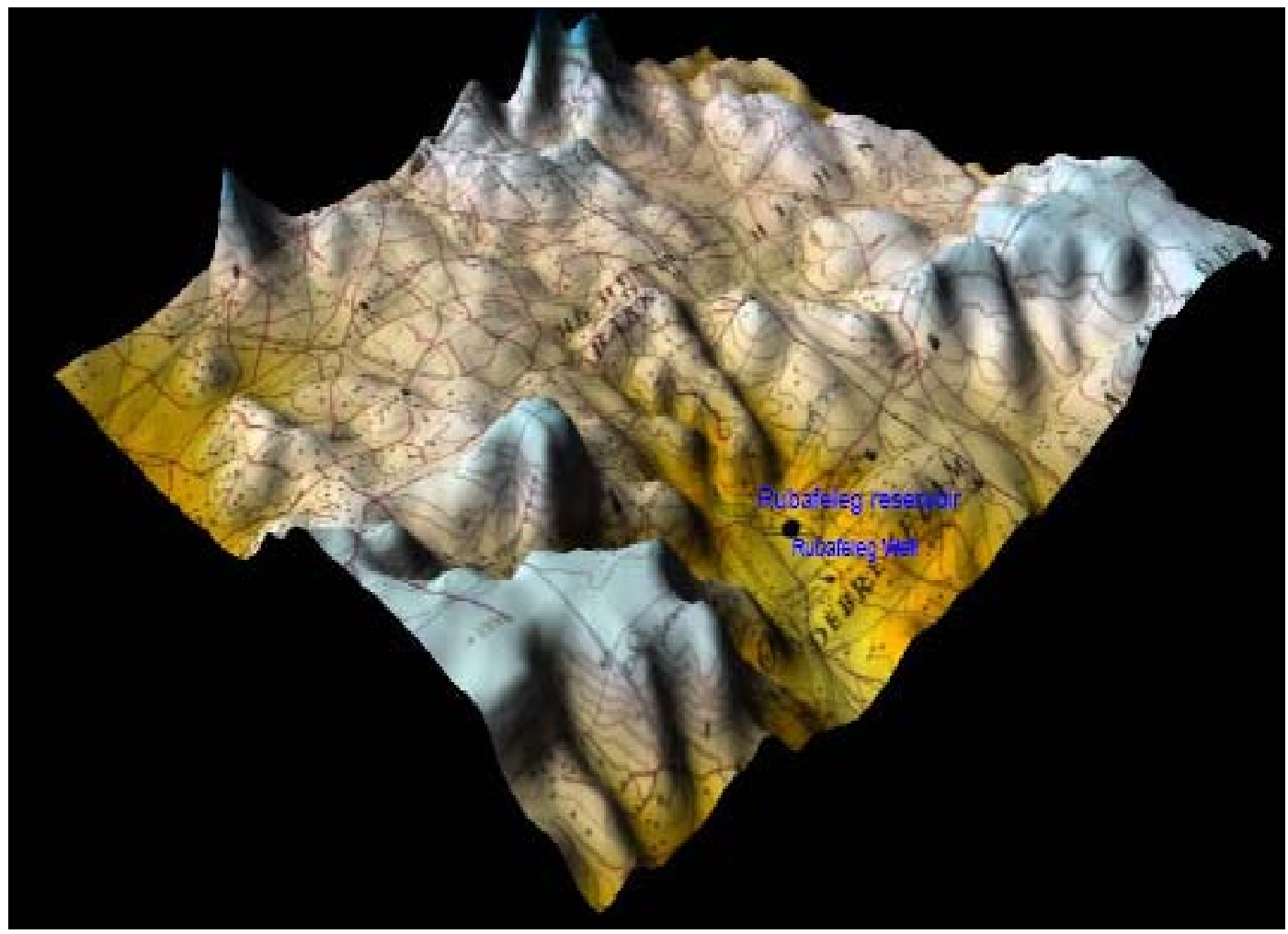

Figure 4. Rubafeleg area Topography 
- The water level in the groundwater is generally found to rise, indicating a continuous accretion of groundwater from the reservoir even though the water in the wells is being continuously used for irrigation particularly during the dry season in Tsinkanet area. As the scope of this paper is to indicate the unseen role of the reservoirs as a groundwater recharging mechanism the focus is in the general trend not on quantifying the volume of water recharged.

- Marshy areas are developed downstream of reservoir.

The above observation indicates that the surface water in the reservoir to interact with the surrounding groundwater. Moreover the surface water is feeding the groundwater down stream enhancing the groundwater system as indicated by development of wet area down stream figure 5.
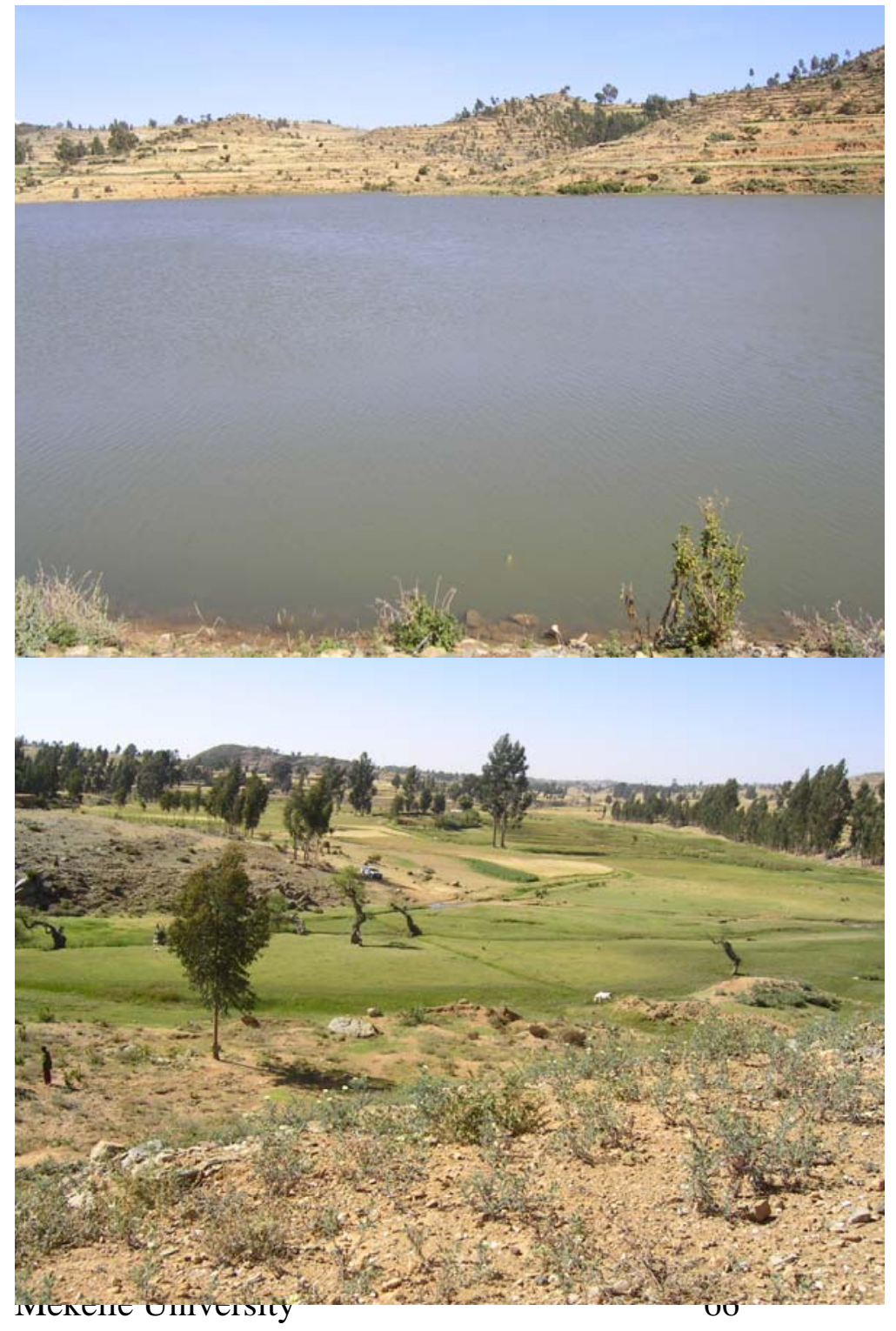

Figure 5. Seepage downstream of Rubafeleg dam (Top, Rubafeleg dam and Bottom, south of the Dam, in the command area) 


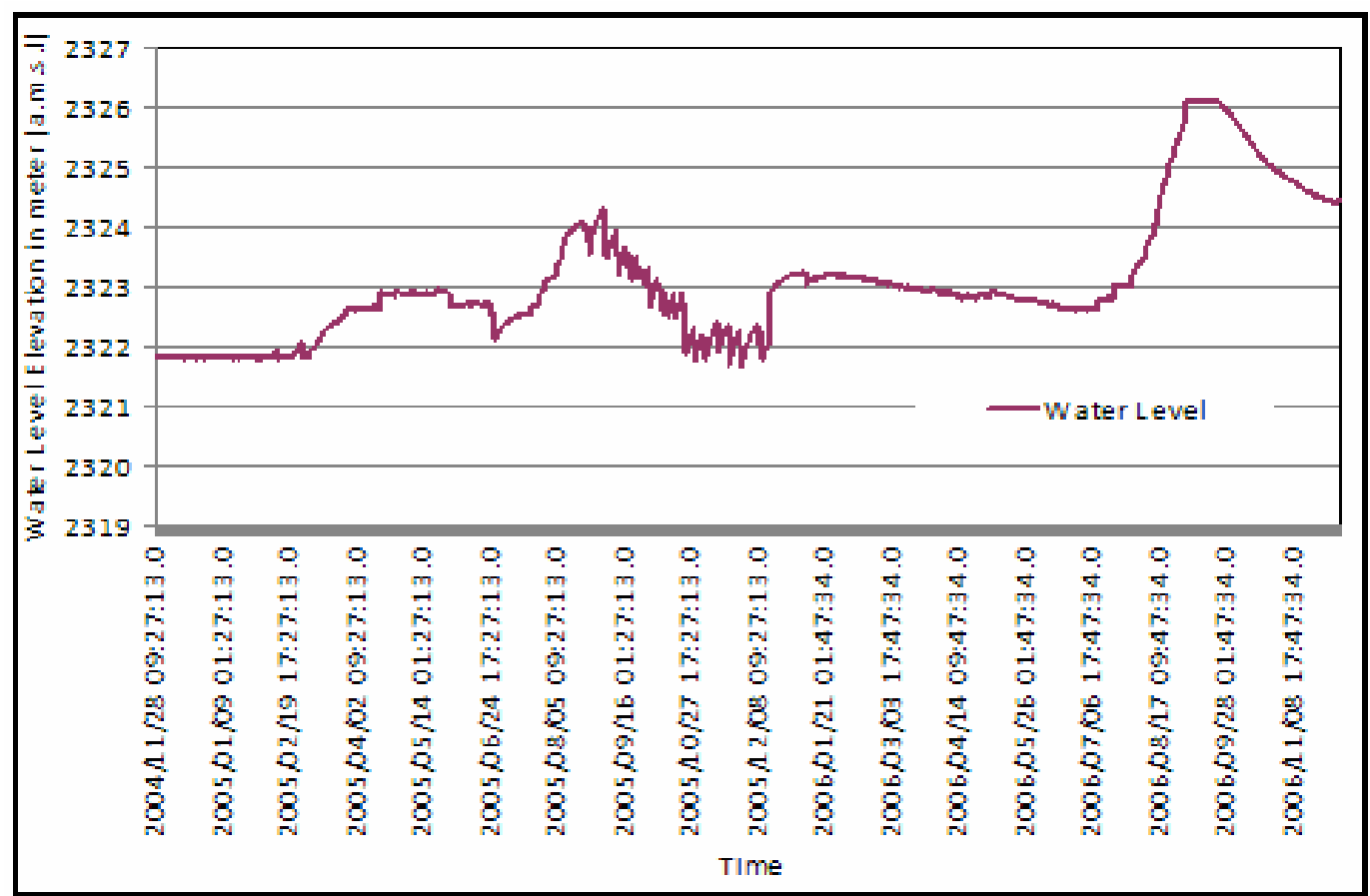

Figure 6. General Water Level rise on Tsinkanet Well 1 (TSW1).

(From Nov. 2004 to Dec. 2006)

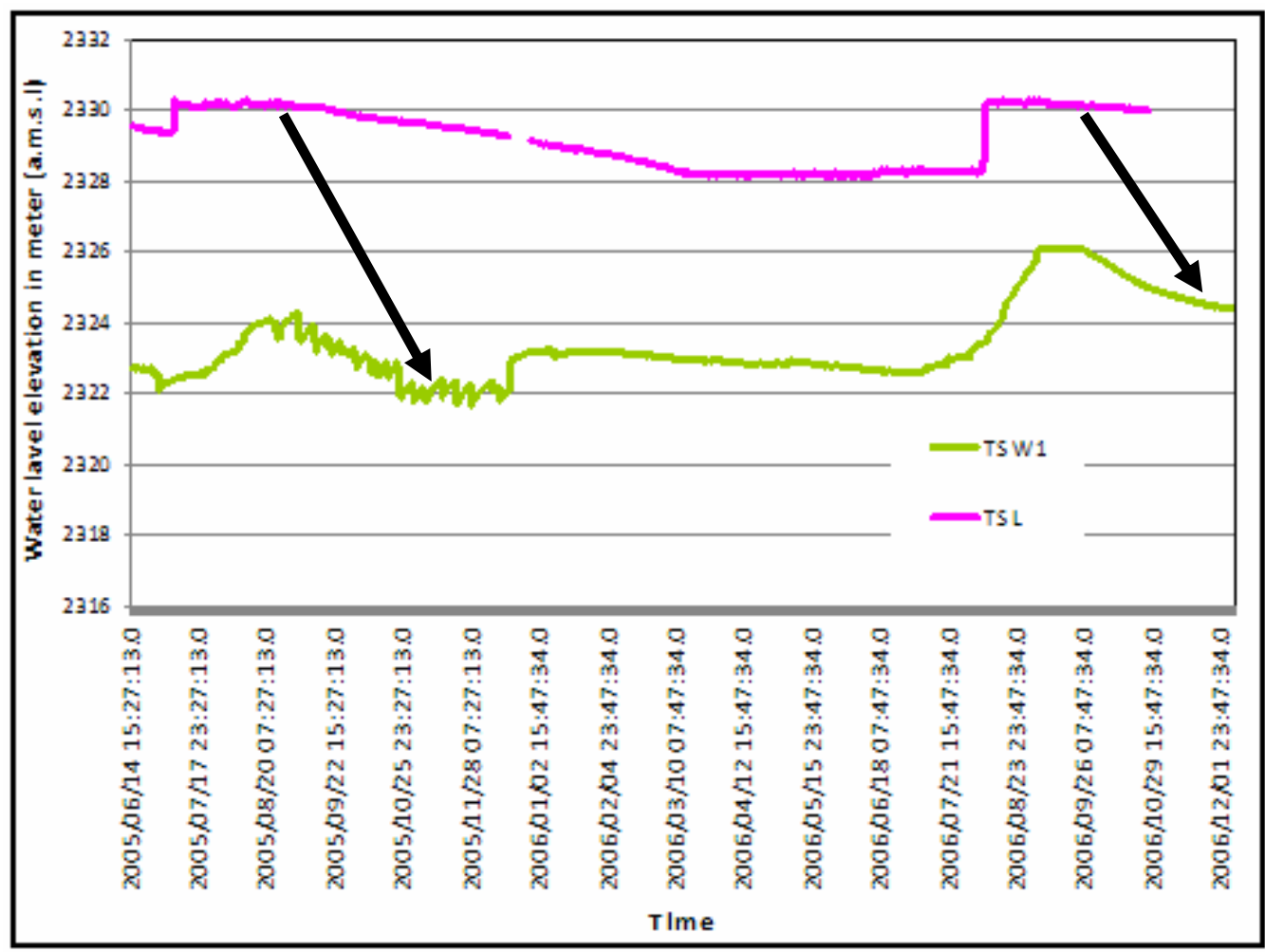

Figure 7. Tsinkanet well 1 (TSW1) being recharged by Tsinkanet micro dam (TSL). (Evidence from water level data from June 2005 to November 2006) 
Table 2. Chemical Characteristics of the samples from Rubafeleg and Tsinkanet.

\begin{tabular}{|c|c|c|c|c|c|c|}
\hline Sample Id & TSW2 & TSL & $R F W$ & RFL & $\boldsymbol{R F} \boldsymbol{R}^{*}$ & $R F S^{* *}$ \\
\hline Location & 558649 & 558723 & 578715 & 578700 & 578615 & 578660 \\
\hline (UTM) & 1548515 & 1549080 & 1541634 & 1540500 & 1442465 & 1541918 \\
\hline $\mathrm{pH}$ & 7.2 & 7.4 & 7.4 & 7.5 & --- & --- \\
\hline $\mathrm{EC}(\mu \mathrm{s} / \mathrm{cm})$ & 202 & 250 & 454 & 181 & --- & --- \\
\hline $\mathrm{Na}(\mathrm{ppm})$ & 13.65 & 9.9 & 17.38 & 5.92 & 20 & 18 \\
\hline $\mathrm{K}(\mathrm{ppm})$ & 1.51 & 3.75 & 0.46 & 1.66 & 4 & 3 \\
\hline Ca (ppm) & 23.28 & 26.8 & 63.83 & 26.5 & 22 & 13 \\
\hline Mg (ppm) & 6.08 & 9.45 & 10.45 & 5.38 & 14 & 15 \\
\hline Fe (ppm) & 0.29 & 0.21 & 0.18 & 0.11 & 1 & 1 \\
\hline Mn (ppm) & nil & 0.01 & nil & 0.01 & 0 & 0 \\
\hline NH4 (ppm) & 0.36 & 0.21 & nil & 0.17 & --- & --- \\
\hline Zn (ppm) & 0.02 & 0.02 & nil & 0.01 & 0 & 0 \\
\hline $\mathrm{Cl}(\mathrm{ppm})$ & 8.39 & 13.92 & 17.89 & 7.95 & 39.48 & 9.69 \\
\hline SO4 (ppm) & 14.82 & 33.11 & 21.63 & 9.28 & 26.03 & 79.28 \\
\hline NO3 (ppm) & 0.94 & 0.38 & 12 & 0.2 & --- & --- \\
\hline NO2 (ppm) & 0.02 & 0.14 & 0.02 & 0.02 & --- & --- \\
\hline HCO3 (ppm) & 95.16 & 128 & 230.58 & 99.43 & 170.32 & 152.37 \\
\hline PO4 (ppm) & 0.03 & 2.89 & 2.89 & 2.89 & 4.545 & 5.01 \\
\hline Si (ppm) & 8.03 & $<7$ & 11.74 & $<7$ & --- & --- \\
\hline
\end{tabular}

* RFR is Rubafeleg River, analyzed at Mekelle University, Earth Science Lab.

** RFS is Rubafeleg spring, analyzed at Mekelle University, Earth Science Lab.

\subsection{Hydro-chemical analysis}

\subsubsection{General chemical characteristics of the water samples in the area:}

The general chemical composition of the water samples has been described with the help of table and graph here. Four samples have been analyzed in Applied Geology Laboratory, Department of Geology and Soil Sciences, university of Ghent, Belgium for major and minor ions. Mekelle University 
Additional two samples were analyzed in the Department of Earth Science, Mekelle University. The results of the analysis are shown on table 2 and Figure 8. The samples are believed to be sufficient considering the size of the target area and the scope of the investigation. Two samples are from Rubafeleg, from the dam and borehole and two samples are from Tsinkanet, again from dam and hand-dug well. The other two samples are from river and spring in Rubafeleg area. As it has been depicted in table 2, the general characteristics of the water sample are more or less similar indicating similar origin and trend.

\subsubsection{Stuyfzand Classification of the water samples:}

To further verify similarities of the water samples from the dam and the groundwater Stuyfzand classification method has been used (Stuyfzand, 1986). Accordingly they are divided into the following.

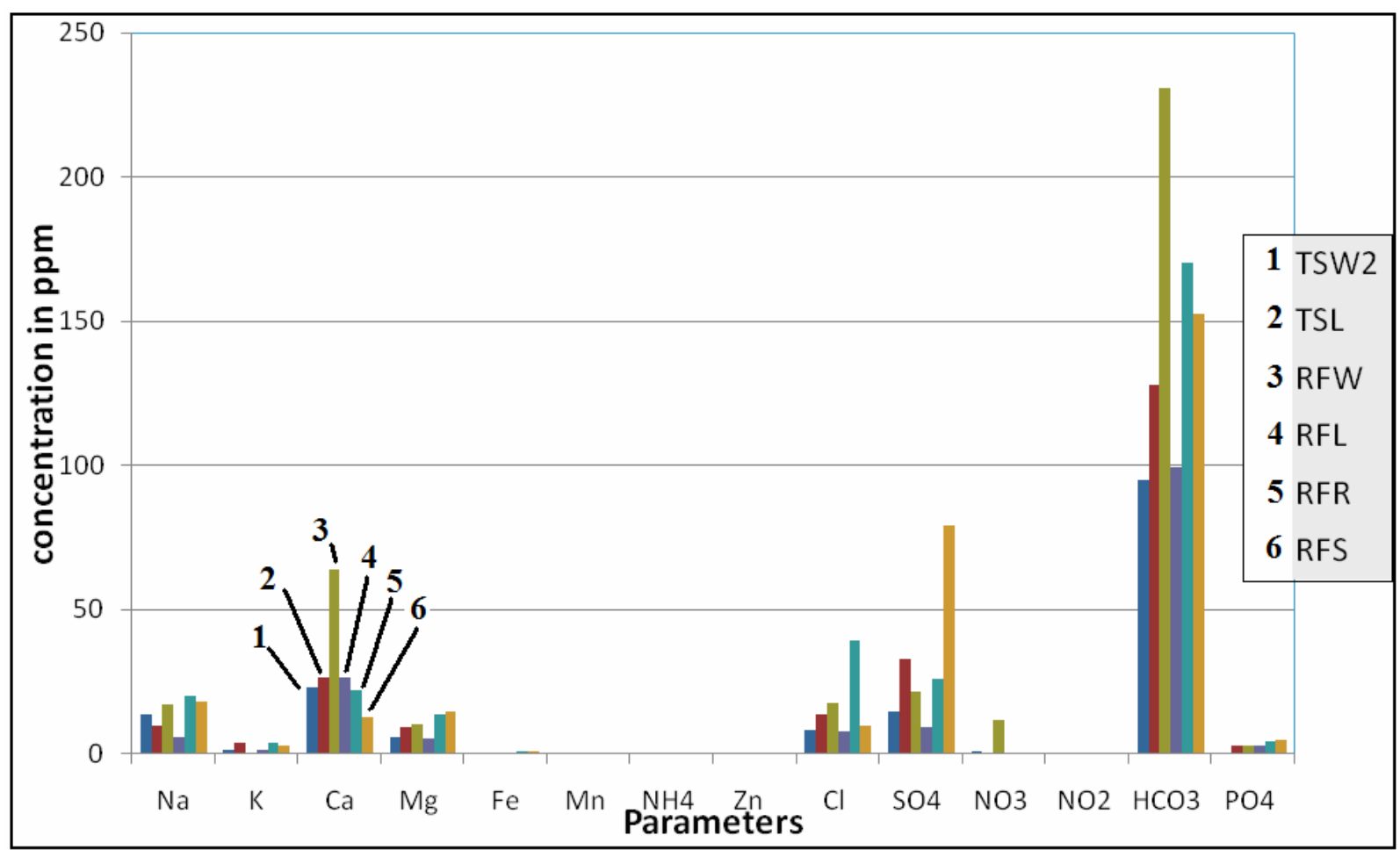

Figure 8. Chemical composition of the samples collected from water points.

1. Main type: it is a function of $\mathrm{Cl}^{-}$content.

The chloride concentration of the samples ranges from $7.95 \mathrm{mg} / \mathrm{l}$ to $17.9 \mathrm{mg} / \mathrm{l}$. This indicates all the samples to have a $\mathrm{Cl}$ concentration of less than $150 \mathrm{mg} / \mathrm{l}$, accordingly they are grouped as fresh (F) (Table 3). 
Table 3. Main type classification of water samples.

\begin{tabular}{|l|l|l|l|l|l|l|}
\hline Sample Id & RFL & RFW & TSL & TSW2 & RFR & RFS \\
\hline $\mathrm{Cl}^{-}$concentration (mg/l) & 7.95 & 17.89 & 13.92 & 8.39 & 39.48 & 9.69 \\
\hline
\end{tabular}

2. Type (Hardness Code): This is derived from the total hardness calculated from the following formula.

$$
\mathrm{TH}=2.5(\mathrm{Ca})+4.1(\mathrm{Mg})
$$

Where TH is total hardness in mg/l and (Ca) and (Mg) are also in mg/l

Accordingly the hardness of the samples is tabulated table 4 and found that they range from soft to hard water.

Table 4. Type classification of the water samples.

\begin{tabular}{|l|l|l|l|l|l|l|}
\hline Sample Id & TSW2 & TSL & RFW & RFL & $\boldsymbol{R F R}^{*}$ & $\boldsymbol{R F S}^{*}$ \\
\hline Ca (ppm) & 23.28 & 26.8 & 63.83 & 26.5 & 22 & 13 \\
\hline Mg (ppm) & 6.08 & 9.45 & 10.45 & 5.38 & 14 & 15 \\
\hline Hardness in mg/L & 83.128 & 105.745 & 202.42 & 88.308 & 112.4 & 94 \\
\hline Hardness in mmol/l & 0.83 & 1.06 & 2.02 & 0.88 & 1.12 & 0.94 \\
\hline Hardness name & Soft & Hard & $\begin{array}{l}\text { Moderately } \\
\text { hard }\end{array}$ & Soft & $\begin{array}{l}\text { Moderately } \\
\text { hard }\end{array}$ & soft \\
\hline Hardness code & 0 & 2 & 1 & 0 & 1 & 0 \\
\hline
\end{tabular}

Table 5. Milliequivalents and the proportions for major cations and anions.

\begin{tabular}{|l|l|l|l|l|l|l|l|}
\hline Sample id & Units & \multicolumn{2}{l}{ Ions } & \multicolumn{2}{l|}{} \\
\hline & & $\mathrm{Ca}+\mathrm{Mg}$ & $(\mathrm{Na}+\mathrm{K})+\mathrm{NH}_{4}$ & $\mathrm{Al}+\mathrm{H})+(\mathrm{Fe}+\mathrm{Mn})$ & $\mathrm{HCO}_{3}+\mathrm{CO}_{3}$ & $\mathrm{SO}_{4}+\left(\mathrm{NO}_{3}+\mathrm{NO}_{2}\right)$ & $\mathrm{Cl}$ \\
\hline \multirow{2}{*}{ RFL } & meq & 1.76 & 0.31 & 0 & 1.63 & 0.19 & 0.22 \\
\cline { 2 - 8 } & $\%$ & 85.02 & 14.98 & 0 & 79.9 & 9.3 & 10.8 \\
\hline \multirow{3}{*}{ RFW } & meq & 4.05 & 0.77 & 0.01 & 3.78 & 0.64 & 0.51 \\
\cline { 2 - 8 } & $\%$ & 83.9 & 15.9 & 0.2 & 76.7 & 13 & 10.3 \\
\hline \multirow{3}{*}{ TSL } & meq & 2.12 & 0.54 & 0.01 & 2.11 & 0.7 & 0.39 \\
\cline { 2 - 8 } & $\%$ & 79.4 & 20.2 & 0.4 & 65.9 & 21.9 & 12.2 \\
\hline \multirow{3}{*}{ TSW2 } & meq & 1.66 & 0.65 & 0.01 & 1.56 & 0.32 & 0.24 \\
\cline { 2 - 8 } & $\%$ & 71.6 & 28 & 0.4 & 73.6 & 15.1 & 11.3 \\
\hline \multirow{3}{*}{ RFR } & meq & 2.25 & 0.97 & 0.036 & 2.8 & 0.54 & 1.11 \\
\cline { 2 - 8 } & $\%$ & 69.1 & 29.8 & 1.1 & 62.93 & 12.13 & 24.94 \\
\hline \multirow{2}{*}{ RFS } & meq & 1.88 & 0.856 & 0.036 & 2.5 & 1.65 & 0.27 \\
\cline { 2 - 7 } & $\%$ & 67.82 & 30.88 & 1.3 & 56.56 & 37.33 & 6.11 \\
\hline
\end{tabular}


2. Sub Type: This is quite important to recognize the processes that have determined the water quality.

The milliequivalent concentration has been converted to proportion as Cations group and anions group. Accordingly all the samples have been found to be CaHCO3 type (Table 5).

\section{Class (Cation Exchange Code)}

The code indicates whether the cation exchange has taken place or not and also the nature of the exchange. The sum of $\mathrm{Na}, \mathrm{K}$ and $\mathrm{Mg}$ (meq/l) is corrected for the seawater contribution, determined from the $\mathrm{Cl}^{-}$content.

$(\mathrm{Na}+\mathrm{K}+\mathrm{Mg})_{\text {corrected }}=(\mathrm{Na}+\mathrm{K}+\mathrm{Mg})$ measured $-1.061 \mathrm{Cl}(\mathrm{meq} / \mathrm{l})($ see Table 6$)$

Table 6. Class classification of the water samples.

\begin{tabular}{|c|c|c|c|c|c|c|}
\hline $\begin{array}{l}\text { Sample } \\
\text { Id }\end{array}$ & $\begin{array}{l}\text { Measured } \\
\text { (meq) } \\
(\mathrm{Na}+\mathrm{K}+\mathrm{Mg})\end{array}$ & $\begin{array}{l}1.061 *(C l) \\
\text { (meq) }\end{array}$ & $\begin{array}{l}\text { Corrected } \\
(\mathrm{Na}+\mathrm{K}+\mathrm{Mg})\end{array}$ & $-\sqrt{1 / 2(C l)}$ & Name & Code \\
\hline RFL & 0.74 & 0.23 & 0.51 & -0.33 & $\begin{array}{l}(\mathrm{Na}+\mathrm{K}+\mathrm{Mg}) \\
\text { surplus }\end{array}$ & + \\
\hline RFW & 1.63 & 0.54 & 1.09 & -0.5 & $\begin{array}{l}(\mathrm{Na}+\mathrm{K}+\mathrm{Mg}) \\
\text { surplus }\end{array}$ & + \\
\hline TSL & 1.31 & 0.41 & 0.9 & -0.44 & $\begin{array}{l}(\mathrm{Na}+\mathrm{K}+\mathrm{Mg}) \\
\text { surplus }\end{array}$ & + \\
\hline TSW2 & 1.13 & 0.25 & 0.86 & -0.34 & $\begin{array}{l}(\mathrm{Na}+\mathrm{K}+\mathrm{Mg}) \\
\text { surplus }\end{array}$ & + \\
\hline RFR & 2.12 & 1.18 & 0.94 & -0.74 & $\begin{array}{l}(\mathrm{Na}+\mathrm{K}+\mathrm{Mg}) \\
\text { surplus }\end{array}$ & + \\
\hline RFS & 2.086 & 0.29 & 1.76 & -0.38 & $\begin{array}{l}(\mathrm{Na}+\mathrm{K}+\mathrm{Mg}) \\
\text { surplus }\end{array}$ & + \\
\hline
\end{tabular}

The Stuyfzand (1986) classification has been used to investigate sea water intrusion but as the author suggested it can also be used to determine natural waters which has undergone different processes. In general all the water samples fall in more or less similar group in which among cations $\mathrm{Ca}$ is dominant and among anions $\mathrm{HCO}_{3}$ is dominant. Rubafeleg Well has relatively higher electrical conductivity indicating that it is truly groundwater as compared to the others. Higher $\mathrm{NO}_{3}$ is observed in this well that could be explained with its relative position with respect to the toilet nearby. From the above classification one can see that in both Rubafeleg and 
Tsinkanet areas the water from different sources fall in the same group with more or less similar chemical composition indicating a relationship between the dam water and the groundwater. The chemical composition of the water could be explained by dissociation of silicate minerals mainly plagioclase feldspar and/or K-feldspars as the groundwater flows through the surrounding area or as base flow water into the micro-dam. But this should be further verified by making detailed investigation on the geochemistry of the surrounding rocks.

\section{CONCLUSION}

The study tries to justify the interaction between the surface water in Tsinaknet and Rubafeleg reservoir, from physiographic, water level and hydrochemical point of view it has been found that the surface water is interacting with the surrounding groundwater. In addition the reservoirs constructed for the purpose of surface water harvesting are found to enhance the groundwater system downstream encouraging the use of small hand-dug wells managed by a single family for their subsistence farming.

The study further recommend to make an investigation to quantify the quantitative recharge calculation to be made to further understand the role of this reservoir as groundwater enhancing structure using modeling approach. Moreover a detailed geochemical investigation will further consolidate the findings of the research from hydrochemical point of view.

\section{REFERENCES}

Appelo, C.A.J. \& Postma, D. 1996. Geochemistry, Groundwater and Pollution. A.A Balkema, Rotterdam,

FAO. 2005. FAO's information system for Water and Agriculture (AQUASTAT). http://www.fao.org/nr/water/aquastat/countries/ethiopia/index.stm

Kazmin, V. 1978. Geology of Ethiopian basement and possible relation between the Mozambique and the Red Sea Belts. Egyptian Journal Geology, 22: 73-86.

Said, R. 1993. The River Nile, Geology, Hydrology and Utilisation. Pergamon Press, England, pp. 282.

Seleshi, B. 2007. Water challenges, innovations and interventions for Ethiopia, Think Tank paper on water resource, pp. 10. 
Stuyfzand, P.J. 1986. A new hydrochemical classification of water types; principles and application to the coastal dunes aquifer system of the Netherlands. Proceedings, $9^{\text {th }}$ Salt Water Intrusion Meeting, Delft, 641 - 655.

Tesfamichael, G, F., De Smidt., Hagos, M., Amare, K., Kabeto, K., Hussein, A., Jan Nyssen., Bauer, H., Moeyersons, J., Deckers, J. \& Taha, N. 2009. Tigray Livelihood, Large scale geological mapping of the Geba basin, Northern Ethiopia.

USGS, 2004. Shuttle Radar Topographic Mission, srtm.usgs.gov. 